\title{
INTEGRATED GEOLOGICAL INTERPRETATION FOR MODELING THE COMPLICATED RESERVOIRS; AN EXAMPLE FROM UPPER RUDEIS AND KAREEM RESERVOIRS, AMAL FIELD, SOUTHERN GULF OF SUEZ RIFT, EGYPT
}

\author{
Okeil, M. ${ }^{1}$, Sakran, Sh$^{2}$, Refaat, A. ${ }^{2}$, El-Gamil, S. ${ }^{1}$, Ramzy, M. ${ }^{3}$ \\ ${ }^{1}$ Amal Petroleum Company (AMAPETCO), Cairo, Egypt, ${ }^{2}$ Geology Department, Faculty of Science, \\ Cairo University, Giza, Egypt, ${ }^{3}$ Pico International Petroleum Company, Cairo, Egypt , \\ ${ }^{*}$ Corresponding author: E-mail: mohamedokeilaglan@gmail.com
}

\begin{abstract}
This work is an attempt to convey the significant role of integrated geological interpretation techniques for constructing robust geological model in one of the most complicated and poorly seismically imaged reservoirs in the Southern Gulf of Suez rift basin. An Example has been taken from syn-rift Langhian and Early Serravallian reservoirs that are represented by Upper Rudeis and Kareem stratigraphic sequences. The bad seismic quality is the result of big thickness of Late Miocene evaporites. This hinders the construction of a reliable subsurface geological model of sub-salt reservoirs. As well, many geological and engineering challenges have been recognized particularly in these reservoirs. The 3D geological modeling techniques have been applied after the conventional geological interpretation to acquire more geological reasonability and geometric validity of the study reservoirs. The concerned section of Amal field has been subdivided into four different reservoirs; two of Upper Rudeis Member (UR2 \& UR1) and two of Kareem Formation (Markha \& Shagar). Only, the Upper Rudeis unit-one (UR1) records noticeable influence of syn-depositional fault movements on the thickness and facies pattern distribution. All these reservoirs exhibit different reservoirs connectivity that in turn affects the production performance behavior through the life of the field. This study could hold the key for the future field development plan and further exploration in and around of the main producing zones.
\end{abstract}

Keywords: Gulf of Suez, Amal Field, Geological Modeling, Kareem Reservoir \& Upper Rudeis Reservoir.

\section{INTRODUCTION}

Amal Field represents the northern termination and updip portion of the main normal-fault tilted block (B-trend fault block) in the southern offshore dip province, Gulf of Suez rift, Egypt (Fig. 1). One of the most obstacles that retard the construction of subsurface geological model in the field is the presence of thick evaporites of Late Miocene that masking the seismic structural picture of the sub-salt reservoirs. Over the last 50 years of exploration and drilling in the field and 30 years of oil and gas production, many geological and engineering challenges have been recognized, related to the study section. Among the main challenges; significant variation of the gross thickness, different sandstone accumulation, missing sections debates (faulting or unconformities), fault-blocks evolution, different hydrocarbon contacts, initial reservoir pressure with different gradients and trends, besides the difficult understanding of reservoirs connectivity and production performance. This work integrates all available geological, geophysical and engineering data in incorporation with the regional structural and stratigraphic events to construct 3D reliable geological model in order to solve the main focal problems that related to the reservoirs geometry and connectivity.

\section{REGIONAL GEOLOGICAL SET-UP}

The Suez rift is an intra-continental rift basin that initiated in the Upper Oligocene to Lower Miocene as the northwest extension of the Red Sea rift (Garfunkel and Bartov, 1977; Patton et al., 1994; Schutz, 1994; McClay et al., 1998; Bosworth and McClay, 2001; Bosworth et al., 2005). It consists of three major half grabens that flip in dip polarity from north to south (Moustafa, 1976) (Fig.1A). In the northern and 


\section{Okeil, et al}

southern half grabens the major faults dip to the NE and the strata within the tilted fault blocks dip to the SW. In the central half graben the dip of the major faults changes to the SW and the strata dip to the NE (Patton et al., 1994). The three half grabens are separated by two accommodation zones, Galala-Abu Zenima accommodation zone (GAZAZ) in the north and Morgan accommodation zone (MAZ) in the south (Moustafa, 1976; Moustafa, 2002). Amal field lies in the southern dip province of the Gulf of Suez rift where several tilted fault blocks are present. These large SW tilted fault blocks are bounded on their up-dip sides by major NE dipping rift-parallel normal faults named, from west to east: Esh El-Mellaha, Gebel Zeit, B-trend, Gebel Zeit, Ghara and Eastern blocks (Afifi et al., 2016) (Fig.1B). Amal field is located at the northern and updip portion of the B-trend fault block; this block is an elongated structural pattern encompassing six medium-to-large size producing fields. These, from south to north, are: Helal, East Zeit, Sidky, GS-365, Waly and Amal (Fig.1C).

The stratigraphy of the Gulf of Suez has been discussed by many workers. According to Said, (1990), the stratigraphic succession of the Gulf of Suez province is characterized by 3 main depositional sequences relative to the Miocene rifting events as: pre-rift, syn-rift and post-rift. The general stratigraphy of Amal field (Fig. 2), represents the whole section of the Gulf of Suez, despite of that none of Amal wells reached the Basement rocks.

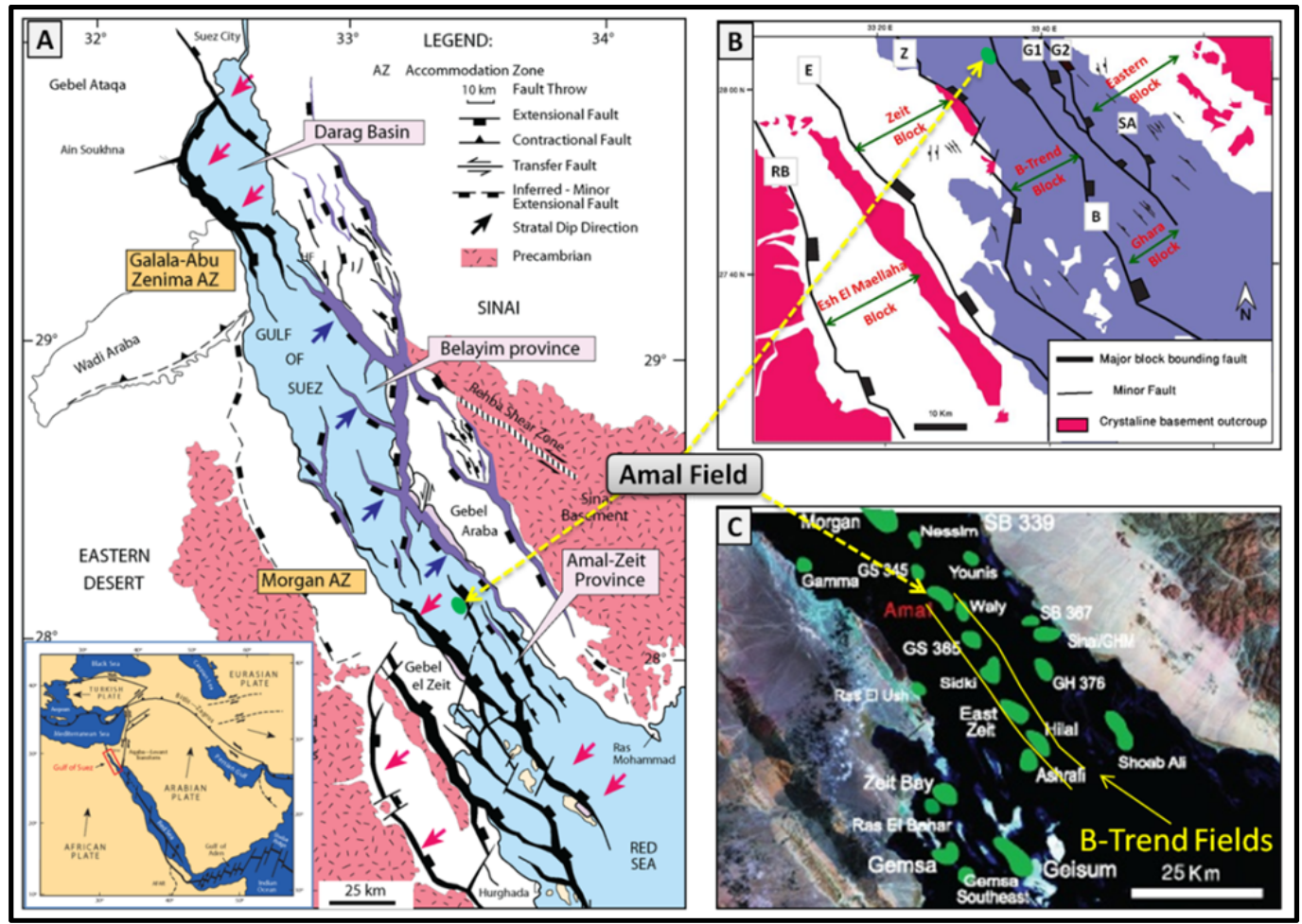

Fig. 1. The location of the Amal Field in the southern dip province of the Gulf of Suez. (A) General tectonic map of the Gulf of Suez (Khalil, 1998; Bosworth and McClay, 2001). (B) Major fault blocks map of the southern Gulf of Suez dip province, The main faults shown are RB: Rift-bounding Fault; E: Esh El Mellaha Fault; Z: Gebel El Zeit Fault; B: B-trend Fault; G1: Ghara Fault 1; G2: Ghara Fault 2; and SA: Shoab Ali Fault (Bosworth et al., 1998; Afifi et al., 2016). (C) Land sate image showing offshore southern Gulf of Suez oil fields.

\section{APPLIED WORK FLOW AND METHODOLOGIES}

This paper presents an integrated workflow for building a robust geological model in such structurally and stratigraphically complex area with a very bad seismic data (Fig. 3). Several conventional geological interpretation techniques have been conducted to study the structural evolution and spatial distribution of the sedimentary rocks in the study area. These techniques and methods include entire detailed bio-litho correlation, isopach maps, reservoir-unit sand isolith maps, fault surface maps, and problem solving 
structural cross-sections. All of that are used to construct a preliminary structure model of the area. The resulted preliminary structural model is integrated with seismic data (guided interpretation) to produce most reliable geological interpretation consistent with the context of regional geology. 3D geological modeling techniques have been used to acquire more geological reasonability of the study stratigraphic interval. The resulted 3D geological model can be used as the main input for dynamic modeling and simulation.

Fig. 2. General stratigraphic column of Amal field (modified after El-Gamil and Shaker, 2000).

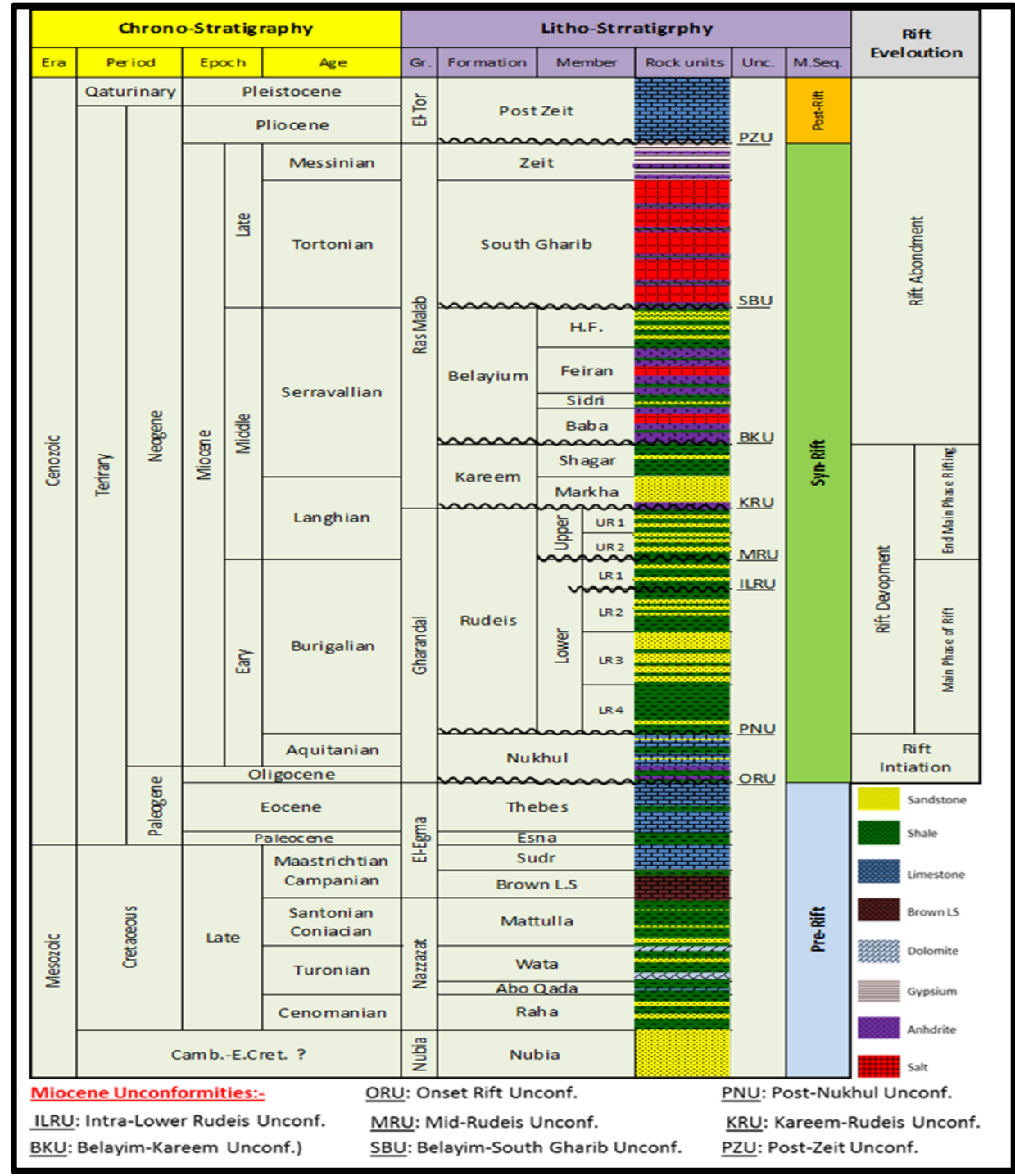

\section{GEOLOGICAL INTERPRETATION}

The bio-litho correlations (chrono-correlation) have been conducted to all the availab0le wells in the field and some reference wells. These correlations were performed using essentially the traditional wire line logs and the paleontological data. The main challenge in the correlation process is detection of the boundary between Kareem and Rudeis formations. This boundary is hardly to be detected in case of the absence of the anhydrite marker at the base of Kareem Formation.

The formation names in the present study are partly based on the scheme proposed by (N.C.G.S, 1976; Douban et al., 2002). The study Middle Miocene succession is classified into Upper Rudeis Member and Kareem Formation. Upper Rudeis Member is subdivided into UR2 and UR1 units while Kareem Formation is distinguished into Markha and Shagar Members. The following is a brief description for these units from older to younger. 
Okeil, et al

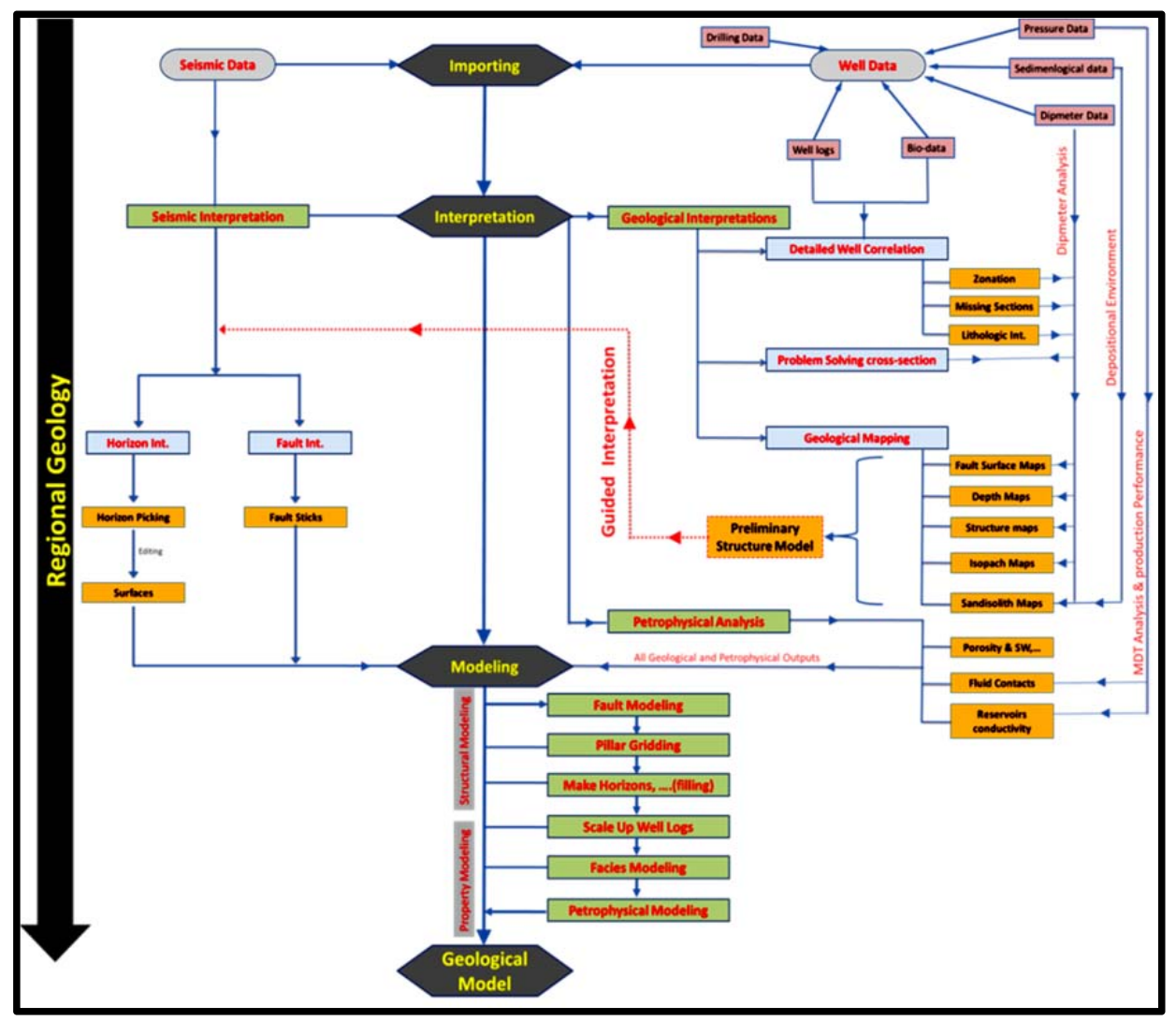

Fig. 3. Integrated work flow chart for constructing the geological model (Based on petrel software).

The shales and sandstones of the Upper Rudeis Member extend laterally with variable thickness over the entire field with average thickness about $70 \mathrm{~m}$, while the maximum thickness of this section reaches about $120 \mathrm{~m}$ and the minimum thickness is $40 \mathrm{~m}$. This variation in thickness is interpreted due to the fault activation during the deposition of the upper unit of Upper Rudeis Member which is associated with Kareem-Rudeis unconformity. The upper Rudeis Member is subdivided into two units from base to top UR2 and UR1(Fig. 4).

Fig. 4: Stratigraphic log correlation panel of the study section through wells 1,2 and 3 (see well locations on Fig. 6), (MRU, KRU and BKU are unconformities and unit boundaries), the panel is flattened on base Kareem Formation.

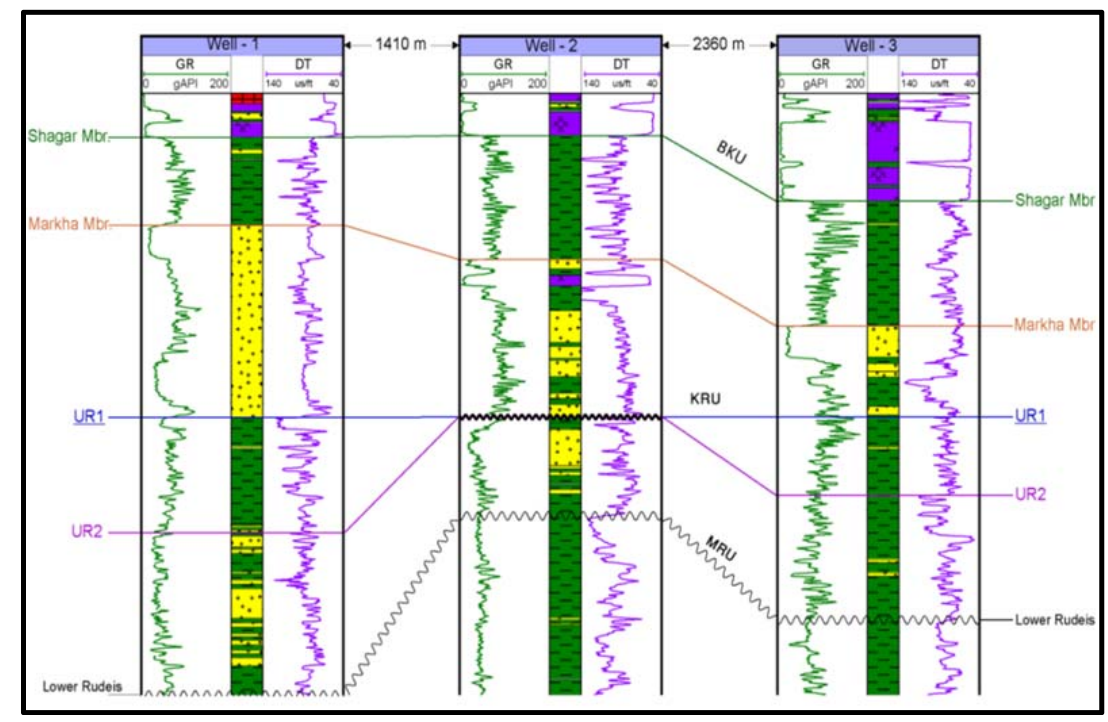

\section{Upper rudeis unit-2 (ur2)}

UR2 represents the lower unit of Upper Rudeis Member. It is widely distributed in the entire area with average thickness about $50 \mathrm{~m}$. This unit consists mainly of shale and sandstone streaks. The sandstone is 
Integrated geological interpretation for modeling the complicated reservoirs

mainly concentrated in the central area (Fig.5A). It is ranging from $0.5 \mathrm{~m}$ to $28 \mathrm{~m}$. It is expected that the sediment source was coming from SW. The base of UR2 marked the boundary between Lower Rudeis and Upper Rudeis and it was easily to be detected by integrating the bio-data and log signatures especially sonic and density logs. The clear bio-marker is represented by the boundary between NN4A and NN4B in Calcareous Nannofossils zones and between N7 and N8 in Calcareous planktonic Foraminifera. The upper boundary with UR1 is also easily detected by the last appearance of P. curva that belongs to N8 bio-zone and the first appearance of P. glomerosa. This is matched with the good boundary of NN4B and NN5 and the very clear distinctive marker on sonic log (Fig. 4). This unit is chronologically equivalent to wellknown Asl Member according to ( N.C.G.S, 1976; Pivnik et al., 2003; Hewaidy et al., 2016) .

\section{Upper Rudeis unit-1 (ur1)}

It extends laterally of very variable thickness with abrupt lateral change in thickness and facies over the entire field. It ranges in thickness from zero to $50 \mathrm{~m}$. This unit is encountered only in $40 \%$ of the drilled wells. The missing section of this unit is mainly concentrated in the central area of the field, being interpreted as a result of Kareem-Rudeis Unconformity (KRU) rather than normal faults (Fig. 5B). A Vigorous work has been done to identify the main reason of the missing section. (Tearpock and Bischke, 1991) reported that the missing section as a result of an unconformity can be mistaken for missing section due to normal fault. Several geological observations weighted the unconformity scenario rather than faulting, supported with; (A) All the missing sections are in the same or nearly the same correlative depth. (B) These correlative sections can't be solved by several normal faults to result the missing in the same interval. (C)The dipmeter data can't support the idea of several normal faults in closely spaced wells. (D) The complete preserved thickness of the overlying Markha Member above the unconformity surface. (E) The presence and aerial distribution of anhydrite at the base of Markha Member (Fig. 5E). (F) This missing part is correlative with the well-known regional Kareem-Rudeis Unconformity (KRU).

The sandisolith map (Fig. 5B) shows the concentration of sandstone facies in two areas, the southern area where the sandstone thickness reaches up to $30 \mathrm{~m}$ and the eastern area with little sandstone accumulation of about $15 \mathrm{~m}$. It is expected that the source of the sand sediment was coming from SW and the sand sediments passed across faults to the NE area.

UR1 unit is overlain by Kareem Formation where the base of Kareem Formation is defined by the existence of Lower anhydrite which is well marked on electric logs, but it is not widely extended throughout Amal field wells. Only $25 \%$ of the total drilled wells encountered this anhydrite. In the case of absence of basal anhydrite, the boundary between Rudeis and Kareem formations could be detected based on the integration of biostratigraphic analysis and visual log patterns recognition especially after the identification of the top of UR2. Many of previous studies on Amal field considered that the top of Rudeis Formation is detected by the boundary of NN5/NN4 of Calcareous Nannofossils zones and between P. curva and P. glomerosa of Calcareous planktonic Foraminifera. While, this bio-marker is interpreted by many authors to be located within the upper Rudeis Member (Martini, 1971; El-Heiny and Martini, 1981; Evans, 1988; Marzouk, 2009; Farouk et al., 2014; Hewaidy et al., 2016). This unit might be chronologically equivalent to Mreir Member according to (N.C.G.S, 1976) or the lower unit of Lagia Member of Ayun Mousa Formation in some classifications (Pivnik et al., 2003).

\section{Kareem Formation}

Kareem Formation is recorded in all Amal wells with slight variable thicknesses over the entire field. Kareem Formation is subdivided into two main members; Lower one: Markha Member with predominant sandstone with shale and anhydrite streaks, and upper one: Shagar Member that is composed mainly of shale with sometimes sandstone streaks. The top boundary is clearly determined by the wide spread regional unconformity (BKU) that separates Belayim evaporites (Baba Member) and shale of Upper Kareem (Shagar Member) which is well marked in log correlation (Fig. 4).

\section{Markha member}

It is recorded in all Amal wells with slightly variable thickness averaging about (55 m) with local increase in the central, northwestern and southeastern parts where the thickness reaches to $100 \mathrm{~m}$, and the 


\section{Okeil, et al}

minimum recorded thickness is $30 \mathrm{~m}$. The base of Markha Member is defined by the possible existence of Lower Kareem anhydrite which is well marked on electric logs and is well known anhydrite marker in the Gulf of Suez province [18]. It is not widely extended throughout the Amal field wells and recorded only in six wells where the thickness ranges from $1.5 \mathrm{~m}$ to $5 \mathrm{~m}$ and is concentrated in the southeastern part and northern parts of the field (Fig. 5E). The upper boundary of Markha Member is detected by the Low GR signature marker that recorded in all Amal wells (Fig. 4). This log response reflects the presence of anhydrite at the top of Markha Member where it is locally distributed only in the eastern part with thickness ranges from $1.5 \mathrm{~m}$ to $4.5 \mathrm{~m}$. Many studies have been conducted on the geological and sedimentological aspects of Kareem section in the Amal field area (El-Gamil and Shaker, 2000; Hussein, 1990; Darwish and Hussein, 1991; El Araby et al., 2009). All studies concluded that this unit is deposited as a result of sub-marine fan but there is debate about the source of the sediment. Darwish and Hussein, (1991) and El Araby et al, (2009) mentioned that the source was coming from the southwest direction (Fig. 5D); in contrary an internal study carried by using the same data concluded that the source was coming from northeast direction. But after acquired more data from the new drilling wells, using the data of the neighboring fields, and adjusting the well tops especially the boundary between Kareem and Rudeis formations, it is clear that the southwest source direction is the more reasonable direction, where the sandisolith map of Markha Member reflects the same depositional model with suggested three loops (Fig. 5C \& D).

The present study re-interpretation on formation tops led to noticeable change in the shape of facies distribution maps especially Upper UR1 unit and Kareem Markha Member. The old zonation lumped apart of UR1 with Markha reservoir and considered them as Markha Member especially in the southern part of the field causing a false interpretation in sandstone distribution of the two units where they are extremely different in both facies and structural patterns.

\section{Shagar Member}

This unit is very well defined throughout the field where it uncomformably overlain by evaporites of Belayim Formation. It is represented by slightly uniform thickness averaging about $(50 \mathrm{~m})$ with a gradual decrease towards the west direction. The sandstone distribution is limited only to the northeastern part of the field, with thickness up to $8 \mathrm{~m}$. (Fig. 5 F).

\section{STRUCTURAL MODELING}

A complete structural model was constructed for both Pre-Rift and Syn-Rift horizons. Only four horizons were extracted to maintain the study section, two of them are shown in Figure 6, presenting the main structural framework of the field. Amal field is generally southwest dipping horst block bounded by two main clysmic faults, in the northeast by northeast-dipping fault (B-trend fault) with large displacement, and to the southwest by southwest dipping fault with relatively smaller displacement than the eastern one. The main horst block is dissected by both synthetic and antithetic faults. The main northeast bounding fault is branching in its termination into smaller faults in northern part of Amal and GS346 fields separating the main Amal field from GS46 field. In the northwest area a normal antithetic fault throwing to southwest with about $200 \mathrm{~m}$ displacement separates the downthrown block with a deeper hydrocarbon contact. Generally, the two main bounding faults dissecting Amal area into three main regions: main horst, western, and eastern blocks. The main horst block is subdivided into three sub-blocks; northwest sub-block, Amal main block, and northern sub-blocks (GS345/346 fields).

\section{DISCUSSION AND RESULTS}

The best way to understand the history of the structural deformation is examining the synrift strata deposited on and adjacent to a structural block, while the present-day structural configuration of a fault block is a result of a complex history of fault segment growth, linkage, and displacement transfer (Pivnik et al., 2003). This section discusses the fault blocks activations and their influence on the reservoirs distribution and the present day reservoirs connectivity. 
Integrated geological interpretation for modeling the complicated reservoirs

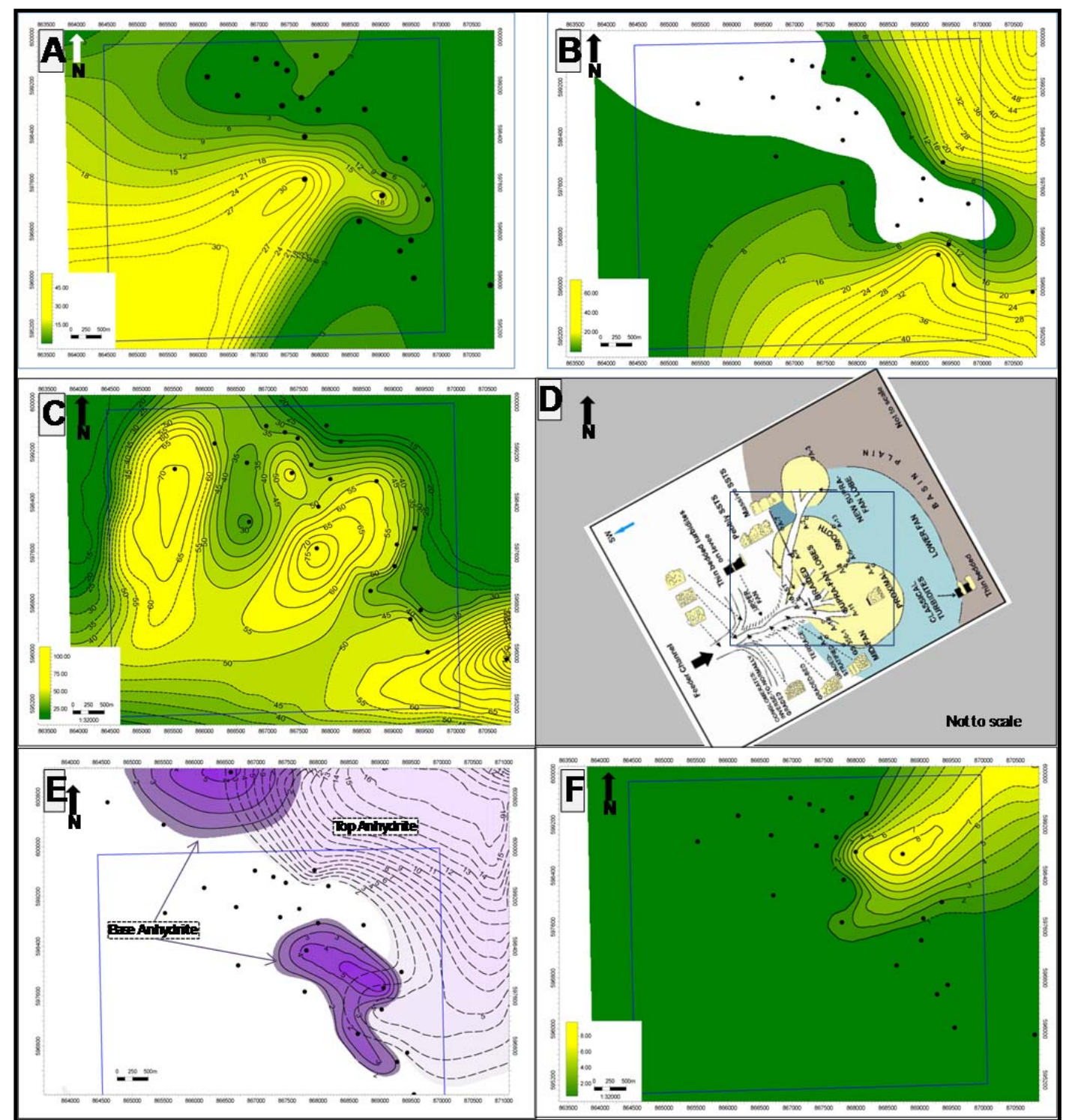

Fig. 5: (A) Sandisolith map of UR2 unit (B) Sandisolith map of UR1 unit, the blank white area represents the missing as a result of KRU. (C) Sandisolith map of Markha Member. (D) Proposed depositional model (submarine fan) of Kareem Formation in Amal Field (El Araby et al., 2009). (E) Base Markha anhydrite map superimposed by top anhydrite contours. (F) Sandisolith map of Shagar Member, the black circles are the penetrated wells.

\section{Fault-blocks evolution}

Synrift sediment thickness patterns in the Amal field area enable us to determine the timing of faulting and block evolution. Generally, the main horst block was formed at the early stage of rift as the footwall of the two bounding faults and their hanging walls represented by the eastern and western blocks. The sub-blocking of the main horst block took place at the last stage of rifting (Fig. 7). It is suggested that happened in contemporaneously with the deposition of Zeit Formation and salt bulging of South Gharib Formation.

The uniform thickness of UR2 unit over the entire field reflects the stable fault activation during the deposition of this unit at Early Langhian time. While the gross interval and net reservoir thicknesses of UR1 show abrupt lateral changes in thickness and facies (Fig. 8). This records a phase of fault movement and deformation in the Amal field area. This abrupt change across faults within the main horst area, indicating that intra-horst faults accommodated most of the deformation at that time and the rest of the block was suffering from non-deposition of that unit. 
Okeil, et al

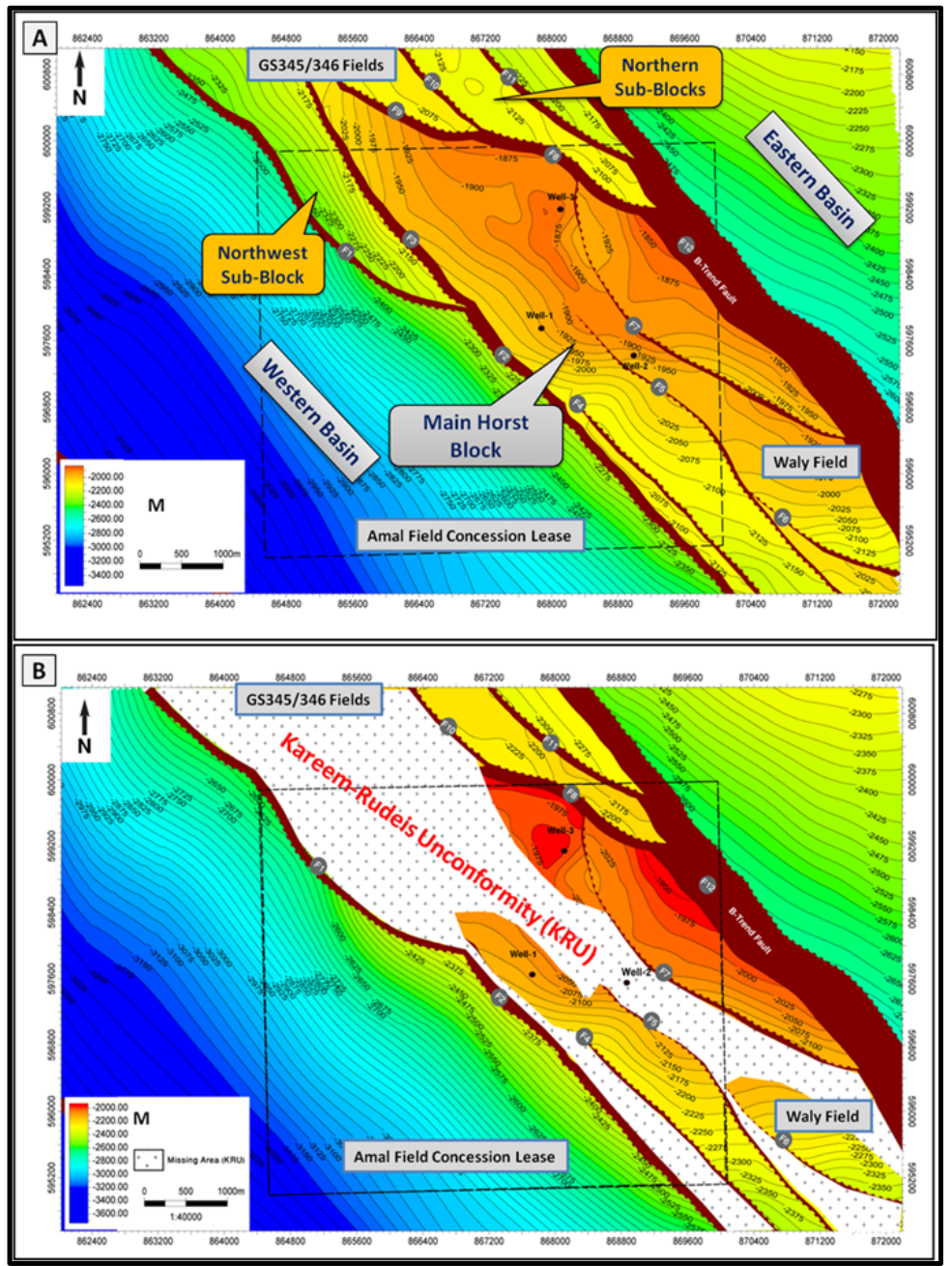

Fig. 6: (A) Structure depth contour map on top of Kareem Fm. (Shagar Member). (B) Structure depth contour map on top of Rudeis Fm. (UR1 unit).

Fig. 7: General diagrams showing Amal field structural evolution during and post the deposition of UR1 unit.

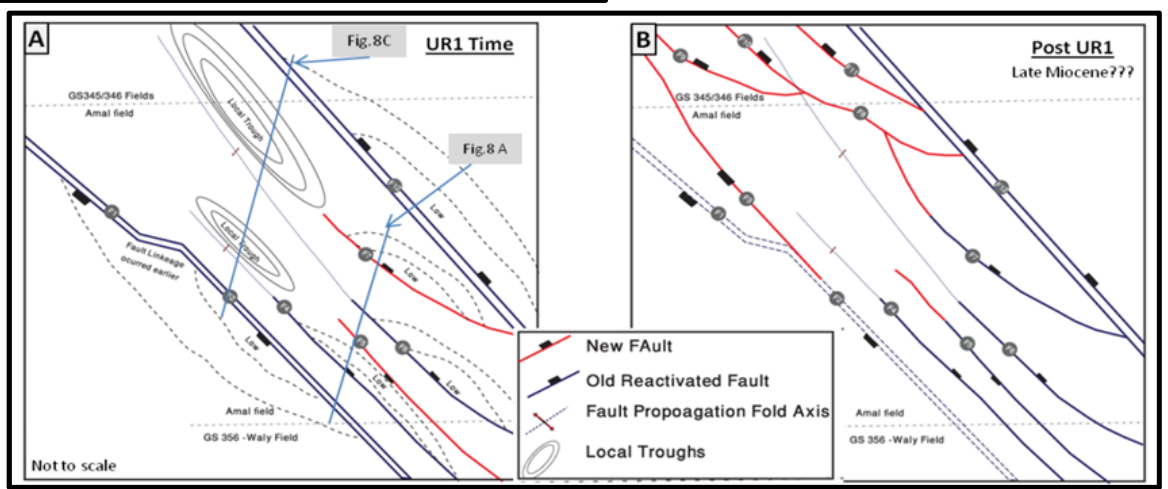

It is suggested that the two main bounding faults of the northeast and southwest were active during the time of deposition of the UR1 causing the main horst block paleo-high resulting the non-deposition of this unit. Otherwise the reactivation of the old faults (F4 and F6) that throwing to northeast in the southern area and tipping out (loses displacement) to the north direction causing the creation of local accommodation for the deposition. The effect of the reactivation was still found in the north areas but without cutting the overlying beds of Upper Rudeis and only forming local doming (fault-propagation fold) with associated troughs (Fig. 7A \& 9C). These troughs created some accommodation spaces for the sediments accumulation that is evidenced by the dipmeter analysis (Fig. 9). These troughs were located in the northern termination of faults (F3 and F5) which extended for F6 outside the Amal field area and affect also the GS346 field area. A new set of small clysmic faults (F5 \& F7) were initiated in the southern 
area in the main horst block creating small accommodations in their downthrown sides. This accommodation incorporated with early reactivated faults where Faults (F4 and F5) bound a narrow graben which affected the stratigraphic thicknesses in the southern area (Fig. 8 \& 9A-B).

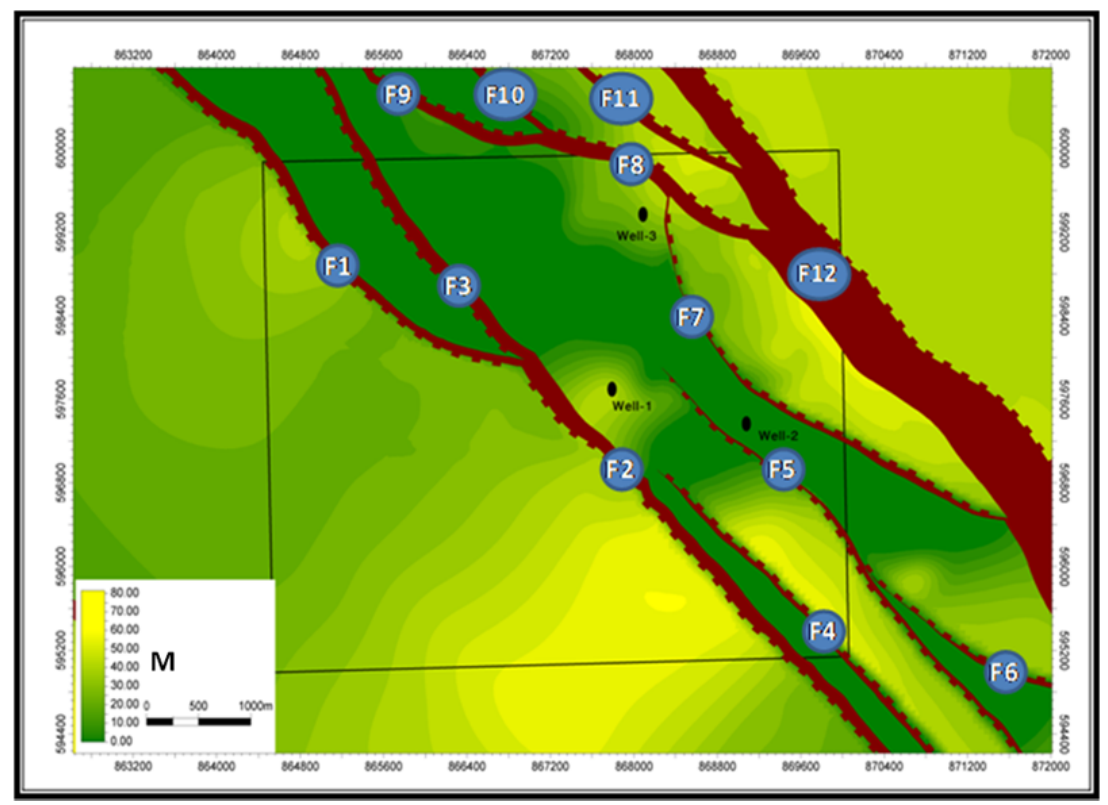

Fig. 8. Isochore map of UR1 unit exported from the 3D model superimposed by the present day structure pattern of UR1, showing the different deepocenters as a result of fault activations at the time of deposition.

It is suggested that the northwest downthrown block was structurally high at Early Langhian time during the deposition of UR1 unit where this unit was not deposited, expecting that fault (F3) was not active at that time and cut after the deposition of this unit (Late Miocene?) (Fig. 7B \& 8).

The uniform gross thickness of the two members of Kareem Formation over the entire field reflects the stable faults activations during the deposition of these units at Late Langhian and Early Serravallian time. The lateral distribution of lower Markha anhydrite is expected to be genetically related to the direction of sediment source that played a vital role for sediment distribution of the two units. In general, there was slight structural stability during the Late Langhian and Early Serravallian of Kareem Formation relative to the time of deposition of upper Rudeis unit.

\section{Reservoirs connectivity}

One of the most important engineering problems in Amal Field is the difficulty of understanding the reservoirs connectivity between the upper Rudeis reservoirs and the Kareem Markha reservoir. There is debate in hydrocarbon contacts; if they have the same contact or different contacts, where in some wells the two reservoirs have different pressure gradients and trends, and other wells have the same trends (Fig. 10).

The study section could be discriminated into four different reservoirs; two of Upper Rudeis Member (UR2 \& UR1) and two of Kareem Formation (Markha \& Shagar). All these reservoirs exhibit different reservoirs connectivity that in turn affects the production performance behavior through the life of the field.

Kareem Shagar reservoir was initially saturated with gas and showed a separation from below three reservoirs where the sandstone streaks are embedded within the shale and are restricted to the northeastern part of the field.

Kareem Markha reservoir generally shows a high degree of lateral continuity all over the field. The main horst area has a common initial OWC at $2167 \mathrm{~m}$ TVDSS and initial GOC at $2060 \mathrm{~m}$ TVDSS, the deeper OWC was encountered in the northwest sub-block at $2226 \mathrm{~m}$ TVDSS. 
Okeil, et al

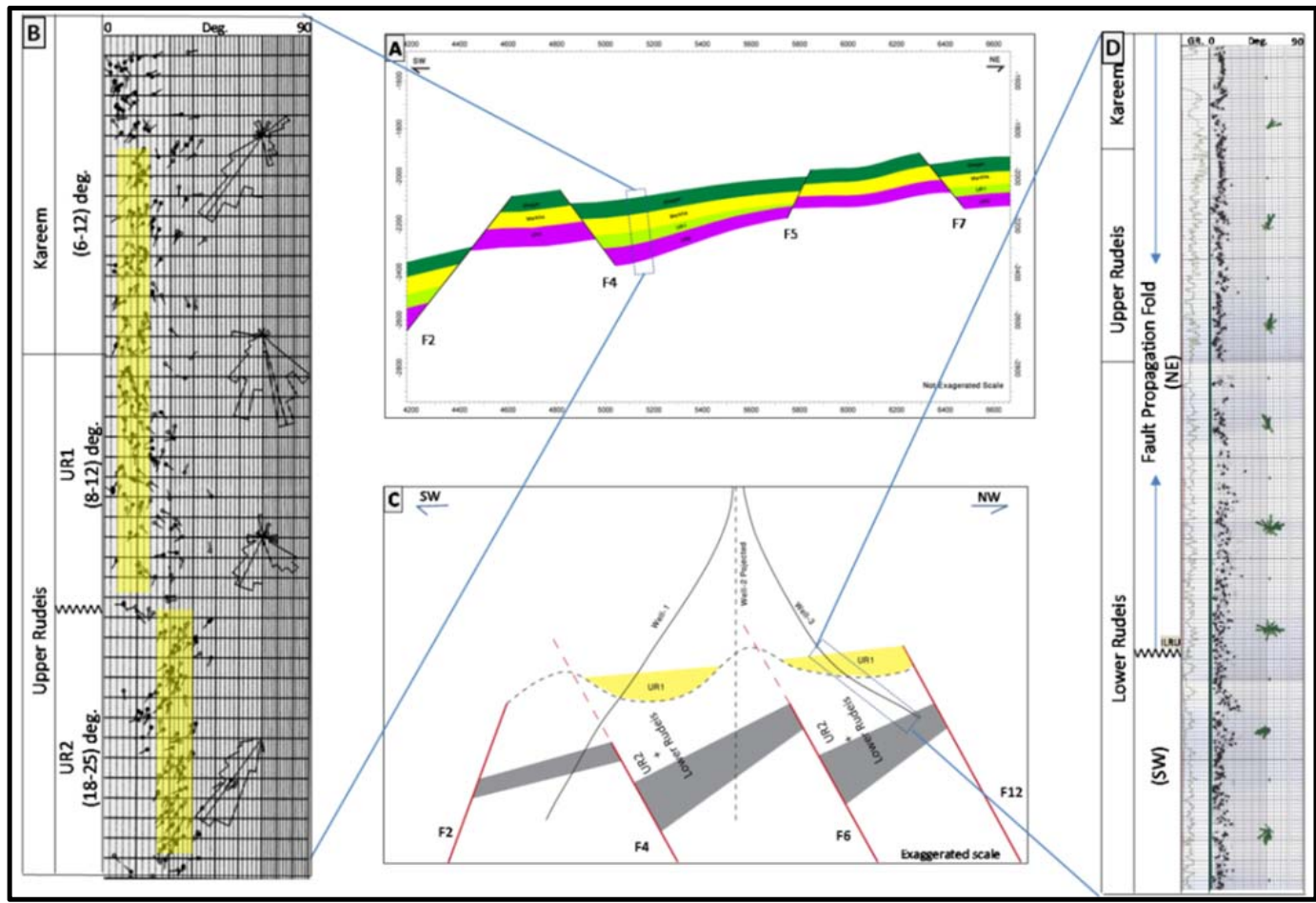

Fig. 9. (A) Structural cross-section representing the deposition of the UR1 unit in the southern part, notice the wedging shape of UR1 between faults (F4 \& F5). (B) Dipmeter log shows the abrupt increase in dip angle in the UR2 unit relative to the overlying beds. (C) Structural cross-section representing the proposed deposition of UR1 in the northern part. (D) Dipmeter log shows the obvious change in dip azimuth in upper Rudeis and Kareem section due to NE direction that different than the normal trend (SW), this interpreted as a result of reactivation of the deepsited fault resulting a fault propagation fold.

Fig. 10: (A) NE-SW crosssection passing through well-1, showing the pinching out of UR2 unit in NE direction. Line of section plotted on Fig. 10B. (B) $3 \mathrm{D}$ view showing the sandstone distribution of UR2 at the area between Well-1 and well-2. (C) Initial reservoir Pressure Vs depth plot showing different oil trends of UR2 and Kareem Markha reservoirs; the two wells have the same oil trend in UR2 reservoir and gas trend in Kareem Markha reservoir.

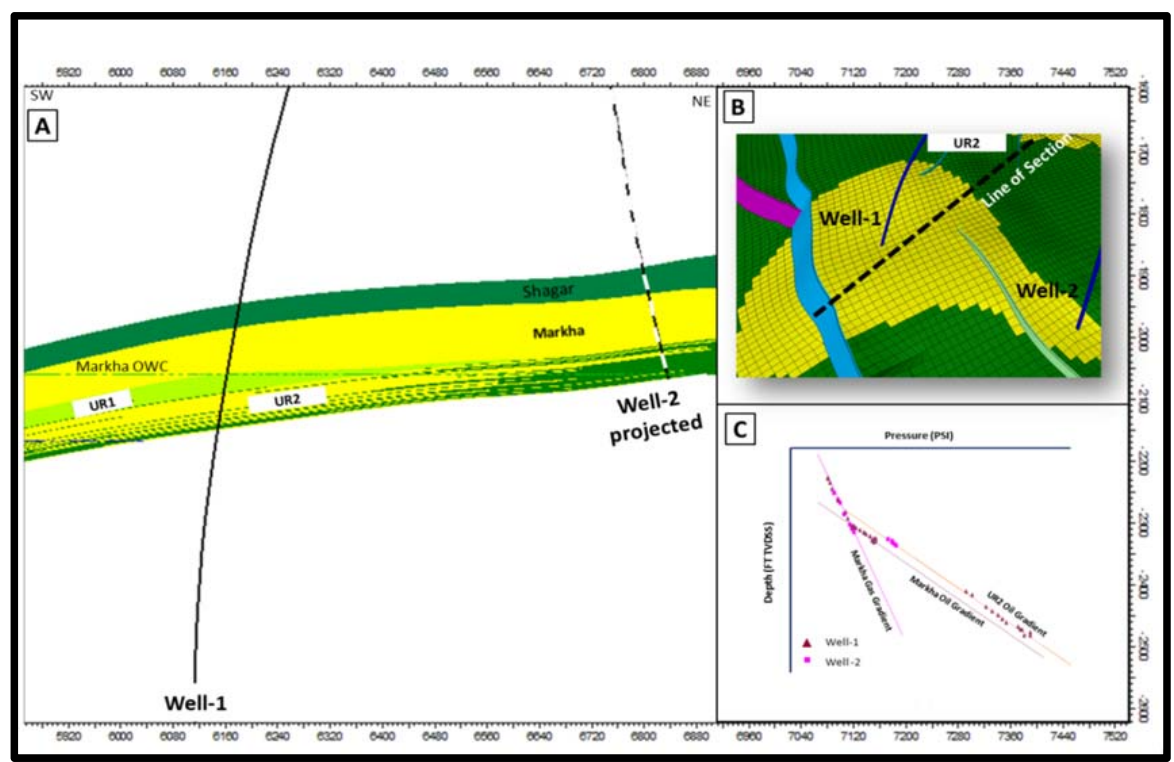

UR1 shows different pressures regimes, due to different reservoir connectivity where the southwestern area has the same pressure of Kareem reservoir due to poor vertical seal. The southeastern area has the same pressure of UR2 due to the partial lateral seal (fault Juxtaposition).

UR2 reservoir was initiated as slightly isolated oil reservoir (Fig. 11) that tested oil at well-2 and produced oil from well-1 with 1.2 MMSTB as a cumulative production through 10 years that led to the 
pressure decrease below the bubble point and formation of secondary gas-cap that was recently encountered in drilled well in the updip direction.

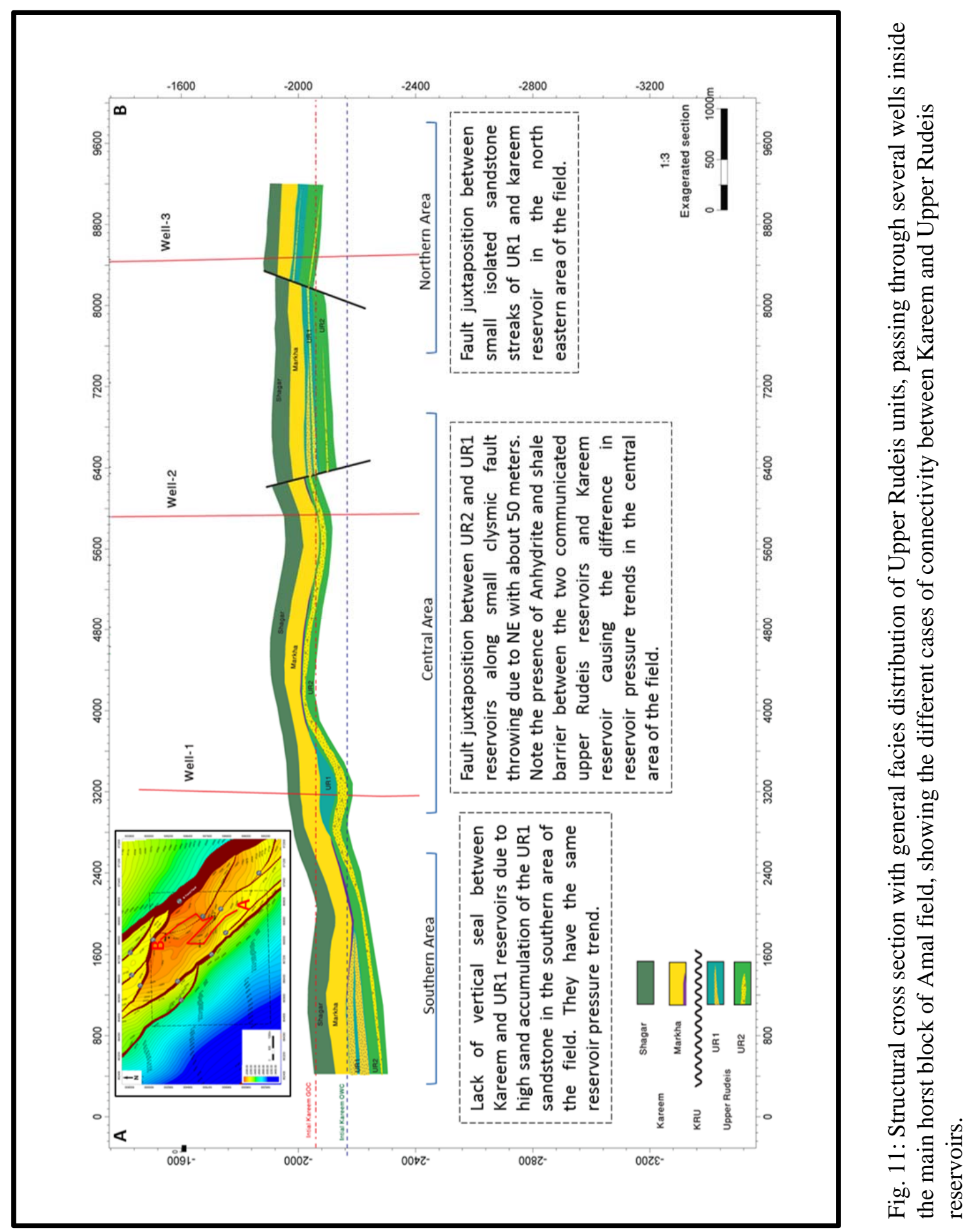

In brief, the reservoir connectivity could be summarized into three different cases/regions of the three connected reservoirs (Kareem Markha, UR1 \& UR2) (Fig. 11):-

At the southern area, the lack of vertical seal between Kareem and UR1 reservoirs, due to high sand accumulation of the UR1 sandstone in the southern area of the field, led to have the same reservoir pressure trend. 


\section{Okeil, et al}

At the central area, the two units of Upper Rudeis (UR2 \& UR1) are dynamically communicated along small clysmic fault (F7) throwing due NE. While the presence of anhydrite and shale barriers between the two communicated Upper Rudeis reservoirs and Kareem reservoir causes the difference in reservoir pressure trends in the central area of the field.

At the northern area, there is fault juxtaposition between small isolated sandstone streaks of UR1 and Kareem reservoirs.

\section{CONCLUSION AND RECOMMENDATIONS}

The closer examination of synrift strata and thickness patterns in the Amal field area enabled us to determine the timing of faulting and block evolution, revealing that fault motions was episodic throughout the Middle Miocene time. The important implications for the prediction of coarse-grained synrift sedimentary rocks on and around normal-fault blocks give the big chance of exploring the southern part of the western basin where large sandstone accumulation was expected in two units of upper Rudeis and Kareem Markha reservoir.

The upper unit of Upper Rudeis Member (UR1) records the influence of syn-depositional fault movements on its thickness and facies pattern distribution. The missing of the UR1 unit on great areas on the main crest of Amal field could be caused by non-deposition during uplift of the block along the two main bounding faults besides the footwall of the small faults within the main horst.

The four study reservoir units (UR2, UR1, Markha and Shagar) exhibit different reservoir connectivity. The first three reservoirs are partially connected to each other in different areas, so it is recommended to simulate them in a single dynamic model, while Shagar reservoir could be simulated separately.

\section{REFERENCES}

Afifi, A. S., Moustafa, A. R. and Helmy, H. M. (2016): Fault block rotation and footwall erosion in the southern Suez Rift: Implications for hydrocarbon exploration. Marine and Petroleum Geology.doi: 10.1016/j.marpetgeo.

Bosworth, W., Huchon, Ph., and McClay, K. (2005): The Red Sea and Gulf of Aden Basins. Journal of African Earth Sciences 43: 334-378.

Bosworth, W. and McClay, K. (2001): Structural and stratigraphic evolution of the Gulf of Suez rift, Egypt: A synthesis. In: Ziegler, P. A., Cavazza, W., Robertson, A.H.F., Crasquin-Soleau, S. (Eds.), Peri-Tethys Memoir 6: Peri-Tethyan Rift/Wrench Basins and Passive Margins, Me'moiresduMuse'um National d'HistoireNaturelle de Paris 186 : 567-606.

Darwish, M. and Hussein, H. M., (1991): Sedimentology and hydrocarbon habitat of the hydrocarbon bearing formations in Amal oil field, Gulf of Suez, Egypt. $2^{\text {nd }}$ Conf. Geochem., Alex., 1 - 48.

El Araby, A., Moneim, A. A. and Darwish, M. (2009):Geological modeling of Kareem Formation in Amal oil field, south Gulf of Suez, Egypt. $1^{\text {st }}$ Symp. Geol. Res. Tethys Realm, Cairo Univ., 1-21.

El-Gamil, S., and Shaker, A., (2000): Amal Field Comprehensive Evaluation (Internal Report).

El Gezeery, M.N., Marzouk, I. M., (1974): Miocene rock stratigraphy of Egypt, The Stratigraphic SubCommittee of the National Committee of Geological Sciences of Egypt. Egypt. J. Geol., 18, 1-59.

El-Heiny, I., and Martini, E. (1981): Miocene foraminiferal and calcareous nanno-plankton assemblages from the Gulf of Suez Region and correlation. GéolMediterr 2:101-108.

Evans, A., L. (1988): Neogene tectonic and stratigraphic events in the Gulf of Suez rift area, Egypt. Tectonophysics, 153: 235-241.

Farouk, S., Ziko, A., Eweda, S., and Said A. E. (2014): Subsurface Miocene sequence stratigraphic framework in the Nile Delta, Egypt. J. Afr. Earth Sci., 91:89-109

Garfunkel, R. L. \& Bartov, Y. (1977): The tectonic of the Suez rift. Geol. Surv. Israel, Bull., 71: 1-44.

Hewaidy, A. A., Mandur, M. M., Farouk, S., and El Agroudy, I. S. (2016): Integrated planktonic stratigraphy and paleoenvironments of the Lower-Middle Miocene successions in the central and southern parts of the Gulf of Suez, Egypt. Arab. J. Geosci., 9:15. 
Integrated geological interpretation for modeling the complicated reservoirs

Hussein, H. M. (1990): Stratigraphic and sedimentological studies on Kareem and Rudeis formations, Amal oil field, Gulf of Suez. M. Sc. Thesis, Fac. Sci., Cairo Univ., 174p.

Khalil, S. M., (1998): Tectonic evolution of the eastern margin of the Gulf of Suez, Egypt. Ph. D. Thesis, Royal Holloway, University of London, 349 p.

Moustafa, A. M. (1976): Block faulting of the Gulf of Suez. Presented at the $5^{\text {th }}$ Exploration Seminar, Egyptian General Petroleum Corporation, Cairo, 223-238.

Moustafa, A. R. (2002): Controls on the geometry of transfer zones in the Suez Rift and NW Red Sea: Implications for the structural geometry of rift systems: AAPG Bull., 86: 979-1002.

Martini, E. (1971): Standard Tertiary and Quaternary calcareous nannoplankton zonation. In: Farinacci, A. (Ed.). Proceedings of the Second International Conference on Planktonic Microfossils Roma, Tecn 2:739-785

Marzouk, A. (2009): Nannofossil biostratigraphy of Miocene section from two wells in the Gulf of Suez, Egypt. Paleontology, Strat, Fazi 532(17):101-127.

McClay, K. R., G. J. Nichols, Khalil, S. M., Darwish, M., and Bosworth, W. (1998): Extensional tectonics and sedimentation, eastern Gulf of Suez, Egypt, in B. H. Purser and D. W. J. Bosence, eds., Sedimentation and tectonics in rift basins, Red Sea-Gulf of Aqaba: London, Chapman \& Hall, 211238.

National Committee of Geological Sciences (N.C.G.S) (1976): Miocene rock stratigraphy of Egypt. Egypt. J. Geol. 18(1):1-59.

Patton, T. L., Moustafa, A. R., Nelson, R. A., and Abdine, S. A. (1994): Tectonic evolution and structural setting of the Suez Rift. - In: London, S. M. (Ed.): Interior rift basins. AAPG, Memoirs, 59: 7-55.

Pivnik, D. A., Ramzy M., Steer, B. L., Thorseth J., El Sisi, Z., Gaafar I., Garing, J. D., and Tucker, R. S. (2003): Episodic growth of normal faults as recorded by syntectonic sediments, July oil field, Suez rift, Egypt. AAPG Bulletin, 87, no. 6, 1015-1030.

Said, R. (1990): The Geology of Egypt. Balkema-Rotterdam, p. 734.

Schutz, K. I. (1994): Structure and stratigraphy of the Gulf of Suez, Egypt, in S. M. Landon, ed., Interior rift basins: AAPG Memoir 59, 57-96.

Tearpock, D. J. and Bischke, R. E. (1991): Applied subsurface geological mapping book. Prentice Hall PTR, Upper Sandle River, New Jersy 07458. Chap. 4:88-90. 
Okeil, et al

\section{تكامل التفسيرات الجيولوجية لتصميم الخزانات المعقدة ، خزاني الروديس العلوي والكريم بحقل أمل جنوب خليج السويس - مصر \\ محمد عقيل' - شوقي سكران' - أحمد رفعت - سعيد الجميل' - محمد رمزيخ 1- شركة أمل للبنرول ، ؟- قسم الجيولوجيا - كلية العلوم- جامعة القاهرة ، r- شركة بيكو للبترول}

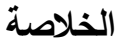

حقل أمل هو أحد الحقول المنتجة من خزانات الميوسين في النطاق البحري الجنوبي لخسف خليج السويس ونوضح هذه الدراسة أهمية تكامل التفسيرات الجيولوجية المخنلفة لبناء نموذج جيولوجي قوي في واحدة من أكثر الخزانات تعقيدًا في المنطقة.

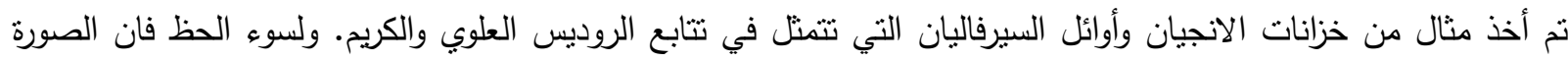

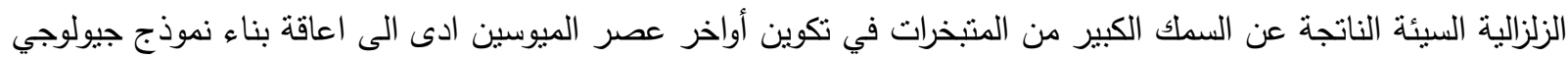
تحت سطح موثوق به لهذه الخزانات. بالاضافة الى العديد من التحديات الجيولوجية والهندية التي ظهرت مع الانتاج التي تحتاج الى تفسير •

تم تطبيق تقنيات النمذجة الجيولوجية ثلاثية الأبعاد للحصول على مزيد من المعقولية الجيولوجية والصدق الهندسي لخزانات

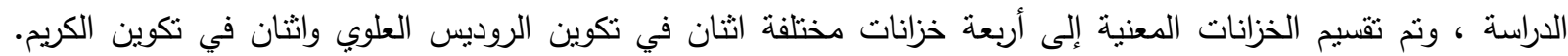
وسجلت الطبقة العليا من تكوين الروديس العلوي تأثيرًا ملحوظًا للحركات الصدعية التى أثرت على نوزيع سمك ونمط السحنات

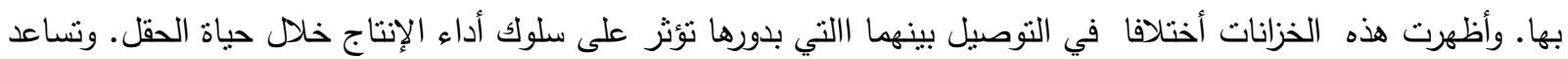
هذه الدراسة في خطة الاستكثاف و التتمية المستقبلية في الحقل. 